\title{
The role of LNG supplies in balancing natural gas demand in EU countries
}

\author{
Rafat Biały ${ }^{1}$, Piotr Janusz ${ }^{1, *}$, Mariusz Laciak $^{1}$, Tadeusz Olkuski ${ }^{2}$, Mariusz Ruszel ${ }^{3}$, and \\ Adam Szurlej ${ }^{1}$ \\ ${ }^{1}$ AGH University of Science and Technology, Faculty of Drilling, Oil and Gas, al. Adama \\ Mickiewicza 30, 30-059 Kraków, Poland \\ ${ }^{2}$ AGH University of Science and Technology, Faculty of Energy and Fuels, al. Adama Mickiewicza \\ 30, 30-059 Kraków, Poland \\ ${ }^{3}$ Rzeszow University of Technology, Department of Economy of the Faculty of Management, al. \\ Powstańców Warszawy 12, 35-959 Rzeszów, Poland
}

\begin{abstract}
Over the last decade, developments could be observed in the structure of primary energy consumption in EU countries. In order to achieve the goals, energy carriers with minimum impact on the natural environment are used, and natural gas is considered to be such a fuel. The share of natural gas in the EU's energy balance in the analysed period, from 2000 to 2016 , remained at a relatively stable level. However, in the case of individual countries, its share in the energy balance depends on specific characteristics of a country. Regardless of the share of natural gas in the energy consumption structure of individual countries, they strive to diversify the supply of natural gas. One of the main constituents of natural gas supply diversification is the construction of LNG import terminals. Access to this infrastructure enhances energy security and offers better opportunities when negotiating long-term contracts for the supply of natural gas. The EU possesses significant possibilities of importing natural gas through LNG terminals, but until now they have been used to a limited extent, it may indicate that in addition to diversification tasks, terminals are a guarantee in the event of interruptions in gas supplies using gas pipelines.
\end{abstract}

\section{Introduction}

Over the last decade, developments could be observed in the structure of primary energy consumption in EU countries. One of the most significant changes is the growing share of renewable energy sources (RES). The demand for natural gas has evolved as well. In the last ten years, the share of natural gas stood at $22-26 \%$ in the structure of EU primary energy consumption. Among EU countries, natural gas share recorded some of the highest levels in 2017 in Italy (approx. 39.7\%), Hungary (approx. 36.8\%) and in the Netherlands (approx. $36 \%$ ) [1]. Against this background, the share of natural gas in Poland's energy balance is clearly lower, standing at $16.1 \%$. However, it is worth noting that Poland is one of the few

\footnotetext{
* Corresponding author: pjanusz@agh.edu.pl
} 
EU countries recording a systematic growth in natural gas consumption, ranging from approximately 11.6 billion cubic metres (bcm) in 2000 to $14.4 \mathrm{bcm}$ in 2007, and to as much as $19.1 \mathrm{bcm}$ in 2017 [1]. The use of natural gas for energy purposes has significant effects and is often a decisive factor that changes natural gas demand in individual EU countries. Table 1 shows the structures of primary energy consumption in EU countries with LNG import terminals, as well as across the European Union, in 2017.

However, whereas in the majority of EU countries a decline in natural gas consumption for energy purposes has been seen in recent years, mainly at the expense of RES, Poland is showing an increasing trend in such use of natural gas, due to several combined-cycle power plants that have been put into operation. This transition from coal to gas in centralized heat and power generation sector helps to reduce air pollution and mitigate adverse health effects [2].

Table 1. Comparison of primary energy consumption structures in EU countries with terminals for LNG regasification in 2017 [\%] (own study based on $[1,3]$ ).

\begin{tabular}{|c|c|c|c|c|c|c|}
\hline & Oil & Natural gas & Coal & $\begin{array}{c}\text { Nuclear } \\
\text { energy }\end{array}$ & $\begin{array}{c}\text { Hydro- } \\
\text { electricity }\end{array}$ & $\begin{array}{c}\text { Other } \\
\text { RES }\end{array}$ \\
\hline Belgium & 51.7 & 22.6 & 4.7 & 15.3 & 0.1 & 5.6 \\
\hline Finland & 35.1 & 5.7 & 14.9 & 18.6 & 12.1 & 13.4 \\
\hline France & 33.5 & 16.2 & 3.8 & 37.9 & 4.7 & 3.9 \\
\hline Greece & 56.1 & 15.0 & 17.6 & 0.0 & 3.3 & 8.0 \\
\hline Spain & 46.7 & 19.8 & 9.7 & 9.5 & 3.0 & 11.3 \\
\hline Netherlands & 47.4 & 36.0 & 10.6 & 1.4 & 0.0 & 4.6 \\
\hline Lithuania* & 54.5 & 33.6 & 3.5 & 0.0 & 1.9 & 6.6 \\
\hline Malta** & $\mathrm{n} / \mathrm{a}$ & $\mathrm{n} / \mathrm{a}$ & $\mathrm{n} / \mathrm{a}$ & $\mathrm{n} / \mathrm{a}$ & $\mathrm{n} / \mathrm{a}$ & $\mathrm{n} / \mathrm{a}$ \\
\hline Poland & 31.0 & 16.1 & 47.7 & 0.0 & 0.6 & 4.7 \\
\hline Portugal & 47.5 & 20.1 & 13.3 & 0.0 & 4.9 & 14.2 \\
\hline Sweden & 28.6 & 1.3 & 3.5 & 27.3 & 26.9 & 12.4 \\
\hline UK & 39.9 & 35.4 & 4.7 & 8.3 & 0.7 & 11.0 \\
\hline Italy & 38.8 & 39.7 & 6.3 & 0.0 & 5.3 & 9.9 \\
\hline
\end{tabular}

* data for the year 2016

** no data

\section{Developments in the EU's natural gas market, role of LNG supply}

Over the last twenty years, developments in the European natural gas market have been very dynamic, mainly due to the evolving demand for natural gas, rapidly declining internal production, market liberalisation, climate policy, investments in the expansion of transmission and LNG infrastructure. In 2000 the consumption of natural gas in the EU accounted for approximately $460 \mathrm{bcm}$. It evolved in the following years, reaching the highest level in 2010 (approx. $521 \mathrm{bcm}$ ), and then $466.8 \mathrm{bcm}$ in 2017. The production changed as well following the evolving demand for natural gas in the EU. A sharp decline from 242.6 $\mathrm{bcm}$ to $117.7 \mathrm{bcm}$ was registerered between 2000 and 2017. This means that over the 17-year period the production of natural gas in the EU decreased by more than half [1].

An evolving demand for natural gas and a sharp decline in production resulted in the need to import more than $349 \mathrm{bcm}$ of natural gas from non-EU suppliers in 2017. It seems certain that in the future (even when assuming that natural gas consumption will not increase) in order to guarantee the security of gas supply, it will be necessary to expand the existing import infrastructure. The situation is likely to get worse after 2030 when additional quantities of natural gas will be needed to decarbonise the power sector (which is reinforced by the lack of significant projects using CCS technologies). As forecast by [4], due to a 
decreasing production of natural gas in the EU, the share of gas imported from the Russian Federation may increase from $30-35 \%$ to $40-50 \%$ in the late 2020 s. Russia is building its international position using an appropriate export strategy for energy carriers and is currently carrying out more and more intensive activities in the Arctic area [5]. Such a heavy dependence on supplies from one of the sources may adversely affect the EU's energy security. Restrictions on natural gas deliveries from the East happened in the past, and an example of one such situation is the gas dispute between Russia and Ukraine in 2009 that affected a number of European countries [6,7]. The effects of a new gas pipeline Nord Stream 2 that could double the existing capacity of gas transport to the EU, bypassing the countries of Central and Eastern Europe, are also debatable. An alternative to natural gas imported from the Russian Federation may be a fuel imported from reserves owned by Israel [8] and Azerbaijan, but this requires Tanap/Tap and Eastern Mediterranean projects to be completed faster [9]. Regardless of the structure of gas deliveries to the EU, the energy security of its member states may be enhanced by promoting the integration of local natural gas markets. To this end, an appropriate cross-border infrastructure is needed. This issue has been recognised by the European Commission. The European Network of Transmission System Operators of Gas (ENTSOG) has drawn up a list of 2013-2022 TYNDP projects (the Ten Year Network Development Plan) in gas infrastructure with a total value of EUR 72.77 billion, where $83 \%$ relates to the expansion of transmission infrastructure, and the remaining $17 \%$ support the development of LNG projects and infrastructure for natural gas storage [10].

Next elements to affect the European natural gas market in the future will be energy policy and competitive gas prices compared with other fossil fuels and RES, mainly in the electricity generation sector [11]. Development of RES technologies helps reduce $\mathrm{CO}_{2}$ emissions, which increases the chance of meeting climate policy objectives set at COP21 and enhances national energy security by reducing dependence on imported raw materials supply. Price competitiveness of fossil fuels other than natural gas may be improved by political decisions (e.g. supporting the mining sector by public subsidies) [4]. To ensure that the price of natural gas is as cost-effective as possible to the final recipient, the EU is implementing reforms to create a common gas market (e.g. through unbundling, TPA and others). Promotion of the competition, market liberalisation, and exchange obligations mean that growing volumes of natural gas are sold in spot markets, thus reducing the share of traditional long-term oilindexed contracts [9]. It seems that a real opportunity to significantly reduce the dependence of EU economy on the supply of pipeline gas from non-EU countries (mainly from Russia, Norway, Algeria and Libya) is the development of infrastructure investments related to LNG. Available information on lessons learned from the exploitation of unconventional resources in the EU leads to a conclusion that in most cases they were unsuccessful [12]. According to information provided by the European Commission, it is estimated that in the period 20172023 the global LNG turnover will increase by more than $100 \mathrm{bcm}$, from 391 to $505 \mathrm{bcm}$ [13].

In recent years the global LNG market has been undergoing big changes. The construction of new liquefaction and regasification facilities has a considerable impact on the EU's energy market [14]. By the end of 2016, the total nominal capacity of liquefaction facilities was 340 million tonnes of LNG/year, and in 2017 it was as much as 365 million tonnes of LNG/year. The import increased simultaneously, reaching globally 289.9 million tonnes of LNG in 2017 (i.e. $364.04 \mathrm{bcm}$ of natural gas under normal conditions). This value was approximately $9.9 \%$ higher compared with the condition in 2016. The competition was increasing. Since 1964, the LNG trade had been based on long-term contracts. At present, spot transactions are of increasing importance. In 2017 deliveries based on the spot market (deliveries made up to 90 days from the trade date) accounted for $20 \%$ of the global LNG supply volume (it was $18 \%$ in 2016) [15]. Such contracts are assumed to be of increasing importance. According to [16], by 2020, 18 LNG cargo deliveries will be available at sea every day, able to be diverted to 
any recipient; FLNGs (Floating Liquefied Natural Gas) and FSRUs (Floating Storage Regasification Unit) will be more and more important in the LNG industry.

Table 2. Characteristics of LNG import terminals in the EU (own study based on [15]).

\begin{tabular}{|c|c|c|c|c|c|}
\hline Country & Site & $\begin{array}{l}\text { Number } \\
\text { of tanks }\end{array}$ & $\begin{array}{c}\text { Total } \\
\text { storage } \\
\text { capacity } \\
\text { LNG }\left[\mathbf{m}^{3}\right]\end{array}$ & $\begin{array}{l}\text { Nominal } \\
\text { send-out } \\
\text { capacity } \\
{[\text { bcm } / y]}\end{array}$ & $\begin{array}{c}\text { Start-up } \\
\text { date }\end{array}$ \\
\hline Belgium & Zeebrugge & 4 & 386000 & 9.0 & 1987 \\
\hline Finland & Pori & 1 & 30000 & 0.1 & 2016 \\
\hline \multirow{4}{*}{ France } & Fos-Cavaou & 3 & 330000 & 8.3 & 2010 \\
\hline & Fos Tonkin & 1 & 80000 & 3.0 & 1972 \\
\hline & Montoir de Bertagne & 3 & 360000 & 10.0 & 1980 \\
\hline & Dunkerque & 3 & 600000 & 13.0 & 2016 \\
\hline Greece & Revithoussa & 2 & 130000 & 5.0 & 2000 \\
\hline \multirow{7}{*}{ Spain } & Barcelona & 6 & 760000 & 17.1 & 1969 \\
\hline & Bilbao & 3 & 450000 & 8.8 & 2003 \\
\hline & Cartagena & 5 & 587000 & 11.8 & 1989 \\
\hline & El Musel & 2 & 300000 & 7.0 & 2013 \\
\hline & Huelva & 5 & 619500 & 11.8 & 1988 \\
\hline & Mugardos & 2 & 300000 & 3.6 & 2007 \\
\hline & Sagunto & 4 & 600000 & 8.8 & 2006 \\
\hline Netherlands & Rotterdam & 3 & 540000 & 12.0 & 2011 \\
\hline Lithuania & Klaipeda & 4 & 170000 & 4.0 & 2014 \\
\hline Malta & Delimara & 5 & 125000 & 0.7 & 2017 \\
\hline Poland & Świnoujście & 2 & 320000 & 5.0 & 2016 \\
\hline Portugal & Sines & 3 & 390000 & 7.9 & 2004 \\
\hline \multirow{2}{*}{ Sweden } & Lysekil & 1 & 30000 & 0.3 & 2014 \\
\hline & Nysahamn LNG & 1 & 20000 & 0.5 & 2011 \\
\hline \multirow{4}{*}{ UK } & Dragon & 2 & 320000 & 7.6 & 2009 \\
\hline & Isle of Grain & 8 & 1000000 & 19.5 & 2005 \\
\hline & South Hook LNG & 5 & 775000 & 21.0 & 2009 \\
\hline & Teesside GasPort & - & - & - & 2007 \\
\hline \multirow{3}{*}{ Italy } & OLT - FSRU Toscana & 4 & 137500 & 3.8 & 2013 \\
\hline & Panigaglia & 2 & 100000 & 3.4 & 1971 \\
\hline & Rovigo & 2 & 250000 & 7.6 & 2009 \\
\hline
\end{tabular}

While analysing the developments taking place in the global LNG market in 2017, we may risk a statement that it was an exceptional year. Several factors had contributed to these developments, but the most significant was the increased involvement of the Unites States, the opening of the Panama Canal for LNG trade and the Northern Route enabling the supply of LNG from the Russian Federation into Europe [17]. 
LNG technology is well known in Europe where the oldest operating LNG regasification terminal entered service in Spain in the late 1960s [18]. At the moment, the expansion of LNG infrastructure is very interesting in the countries of the Baltic Sea basin, i.e. in Lithuania, Sweden, Poland and Finland where five terminals have come into operation in the last seven years. The expansion of LNG infrastructure for the reception and regasification of LNG in the Baltic Sea region may be particularly important during price negotiations while signing long-term contracts [19]. It also considerably enhances national energy security. Table 2 summarises EU member states which by the end of 2017 had terminals for LNG regasification; it also includes the characteristics of EU terminals. The total nominal regasification capacity of all terminals built in the EU in 2017 amounted to nearly $210.6 \mathrm{bcm}$ per year (not including Teesside GasPort). The operation of these facilities under full load would correspond to $60 \%$ of the volume of gas imported into the EU in 2017. The actual LNG supply to the European Union was much lower. By way of example, it amounted to $74.5 \mathrm{bcm}$ in $2010,37.4 \mathrm{bcm}$ in 2013, $41.6 \mathrm{bcm}$ in 2016, and $49.07 \mathrm{bcm}$ in 2017; this was slightly above $14 \%$ of the total volume of natural gas imports into the EU, where Spain, the UK, France and Italy imported a total of approximately $38.41 \mathrm{bcm}$ of natural gas (Table 3), which was around $78 \%$ of the total volume $[1,15,20]$.

Table 3. LNG deliveries to the EU, 2010-2017 [bcm] (own study based on [15] and previous GIIGLN reports).

\begin{tabular}{|c|c|c|c|c|c|c|c|c|}
\hline Specification & $\mathbf{2 0 1 0}$ & $\mathbf{2 0 1 1}$ & $\mathbf{2 0 1 2}$ & $\mathbf{2 0 1 3}$ & $\mathbf{2 0 1 4}$ & $\mathbf{2 0 1 5}$ & $\mathbf{2 0 1 6}$ & $\mathbf{2 0 1 7}$ \\
\hline Belgium & 5.5 & 5.2 & 2.3 & 1.5 & 1.2 & 2.4 & 1 & 1.1 \\
\hline Finland & - & - & - & - & - & - & 0.02 & 0.1 \\
\hline France & 13.1 & 13.4 & 9.1 & 7.5 & 5.8 & 5.5 & 7 & 9.3 \\
\hline Greece & 0.9 & 1.2 & 1 & 0.6 & 0.5 & 0.6 & 0.7 & 1.6 \\
\hline Spain & 26.2 & 22.1 & 18.5 & 11.7 & 10.1 & 11.2 & 12.9 & 15.4 \\
\hline Netherlands & - & 0.7 & 0.7 & 0.5 & 0.6 & 0.8 & 0.5 & 1.0 \\
\hline Lithuania & - & - & - & - & 0.1 & 0.4 & 1.3 & 1.0 \\
\hline Malta & - & - & - & - & - & - & - & 0.3 \\
\hline Poland & - & - & - & - & - & - & 1.0 & 1.6 \\
\hline Portugal & 2.7 & 2.7 & 1.9 & 1.9 & 1.2 & 1.4 & 1.7 & 3.5 \\
\hline Sweden & - & - & - & - & - & 0.4 & 0.3 & 0.4 \\
\hline UK & 17.8 & 23.3 & 13.1 & 8.7 & 10.6 & 12.7 & 9.4 & 6.2 \\
\hline Italy & 8.4 & 8 & 6.5 & 5.1 & 4.1 & 5.4 & 5.8 & 7.6 \\
\hline $\begin{array}{c}\text { Total LNG } \\
\text { import to UE }\end{array}$ & 74.5 & 76.5 & 53.1 & 37.4 & 34.3 & 40.8 & 41.6 & 49.1 \\
\hline
\end{tabular}

The importance of LNG deliveries in balancing the demand for natural gas in EU countries can be evaluated based on data contained in Table 4. The operation of LNG regasification infrastructure under full load would help cover total natural gas demand in 2017 in Greece, Spain, Lithuania, and Portugal. Taking into account the actual quantity of imported LNG, the highest shares in natural gas balances were in Portugal $(55.8 \%)$, Sweden and Lithuania $(50 \%)$, and Spain (48.1\%). In Poland, LNG imports covered approximately $8.4 \%$ of its domestic natural gas demand in 2017 [1, 15]. 
Table 4. Importance of LNG supplies by individual EU countries in 2017 (own study based on $[1,15])$.

\begin{tabular}{|c|c|c|c|c|c|}
\hline $\begin{array}{c}\text { Specifica- } \\
\text { tion } \\
\text { capacity of } \\
\text { terminals for } \\
\text { LNG } \\
\text { regasification } \\
{[\text { Bcm }]}\end{array}$ & $\begin{array}{c}\text { Natural gas } \\
\text { consumption } \\
{[\mathrm{Bcm}]}\end{array}$ & $\begin{array}{c}\text { Imported } \\
\text { LNG } \\
{[\mathrm{Bcm}]}\end{array}$ & $\begin{array}{c}\text { Share of LNG in } \\
\text { covering natural } \\
\text { gas demand from } \\
\text { 2017 assuming } \\
\text { maximum } \\
\text { utilisation of } \\
\text { regasification } \\
\text { capacity of } \\
\text { terminals [\%] }\end{array}$ & $\begin{array}{c}\text { Actual share of } \\
\text { LNG in covering } \\
\text { natural gas } \\
\text { demand taking } \\
\text { into acount } \\
\text { completed } \\
\text { deliveries and } \\
\text { consumption } \\
\text { from 2017 [\%] }\end{array}$ \\
\hline Belgium & 9 & 16.4 & 1.11 & 54.9 & 6.8 \\
\hline Finland & 0.1 & 1.8 & 0.07 & 5.6 & 3.9 \\
\hline France & 34.3 & 44.7 & 9.3 & 76.7 & 20.8 \\
\hline Greece & 5 & 4.8 & 1.62 & 104.2 & 33.8 \\
\hline Spain & 68.9 & 32 & 15.39 & 215.3 & 48.1 \\
\hline Netherlands & 12 & 36.1 & 0.98 & 33.2 & 2.7 \\
\hline Lithuania & 4 & 2.2 & 1.1 & 181.8 & 50.0 \\
\hline Malta & 0.7 & $\mathrm{n} / \mathrm{a}$ & 0.31 & $\mathrm{n} / \mathrm{a}$ & $\mathrm{n} / \mathrm{a}$ \\
\hline Poland & 5 & 19.1 & 1.61 & 26.2 & 8.4 \\
\hline Portugal & 7.9 & 6.2 & 3.46 & 127.4 & 55.8 \\
\hline Sweden & 0.8 & 0.8 & 0.4 & 100.0 & 50.0 \\
\hline UK & 48.1 & 78.8 & 6.17 & 61.0 & 7.8 \\
\hline Italy & 14.8 & 72.1 & 7.55 & 20.5 & 10.5 \\
\hline
\end{tabular}

7000

6000

5000

랑 4000
$\sum_{0} 3000$

2000

1000

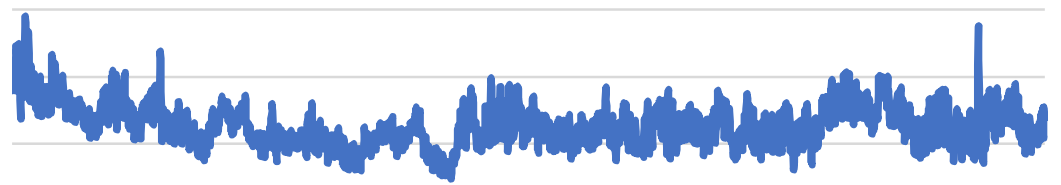

0

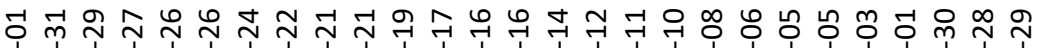

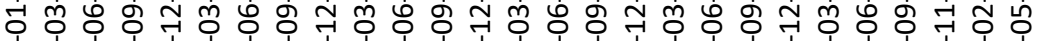

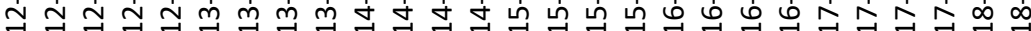

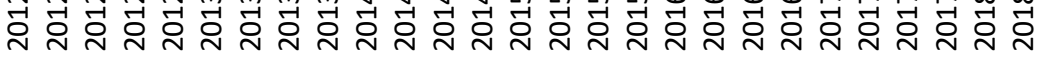

Aggregated gas flou out of the LNG facility send-out during gas day

Declared total reference send-out (send-out capacity)

Fig. 1. The utilisation of regasification capacity in EU terminals (own study based on [21]). 
One of the main parameters describing the development of LNG deliveries in balancing the supply of natural gas to the EU is the utilisation of regasification capacity. In the analysed period, the utilisation of regasification capacity in European terminals ranged from $8.36 \%$ (as of October 18, 2014) to $51.6 \%$ (as of February 1, 2012), while the average utilisation of regasification capacity in the analysed period was only at $21.9 \%$. Figure 1 shows in detail the utilisation of regasification capacities in the EU.

While analysing the utilisation of regasification capacities in individual countries in 2017, it is becoming apparent that the largest utilisation rate at $66 \%$ was recorded in Italy, and LNG covered $16 \%$ of its gas demand. Portugal with its $55 \%$ came second in using regasification capacities, and as much as $58 \%$ of its gas demand was covered by LNG. In other countries the utilisation rate did not exceed $27 \%$. The lowest utilisation rate was noted in the Netherlands, standing at $5 \%$. For a number of years now, Poland has pursued a policy aimed at diversifying not only natural gas sources and origins but also the structure of contracts. One of the key projects in this area was the construction of LNG import terminal in Świnoujście with its regasification capacity of $5 \mathrm{bcm}$ per year [22]. The terminal entered service in May 2016. From that moment, the utilisation of regasification capacity ranged from $7 \%$ (as of July 28, 2017) to $93.9 \%$ (as of May 26, 2018), while the average utilisation of regasification capacity in the analysed period was at $35 \%$. It is worth noting that over the last months deliveries have been carried out not only within the scope of a long-term contract with Qatar but also based on spot deliveries from Norway and the United States [23]. It is worth mentioning that PGNiG had signed a contract for LNG supply with a Qatar company as early as in 2009, while in 2017 another agreement was signed under which the supplies were increased up to 2 million tonnes of LNG/year. The dynamically evolving LNG market also gives incentives to start cooperation with companies offering to bring liquefied natural gas from the United States to Poland. In November 2017 PGNiG signed a contract with a British utility Centrica for the delivery of 9 LNG cargoes to be completed between 2018 and 2022 sourced from Sabine Pass Train 5 terminal, USA; in late June 2018, the company signed preliminary cooperation agreements with Sempra Energy and Woodside company, and Venture Global LNG company [22,24].

\section{Summary}

There has been a significant decline in natural gas production in EU countries in recent years. Only between 2010-2017 the production in EU countries decreased by nearly $58 \mathrm{bcm}$ and in 2017 it was $117.7 \mathrm{bcm}$; thus, it was similar to the natural gas production in Norway, i.e. $117 \mathrm{bcm}$. It is worth noting that as recently as in 2010 these production volumes were substantially different: the EU - $176 \mathrm{bcm}$, Norway - $107 \mathrm{bcm}$. This resulted in increased dependence of EU countries on natural gas imports and in 2017 it was necessary to import $349 \mathrm{bcm}$ of natural gas. The analysis carried out in this paper showed that LNG deliveries may significantly enhance European energy security by reducing growing imports of Russian gas. A relatively low utilization rate of regasification capacity of European terminals $(23 \%$ in 2017) shows significant growth potential (over $160 \mathrm{bcm} /$ year). Even if LNG imports were assumed hypothetically at the record-breaking level from 2011 registered in EU countries, the utilization rate of terminals would increase to $35.7 \%$; so, there is still considerable potential available. Further development of the LNG market, and supply capacities in particular may be a driver for increasing LNG share in balancing the demand for natural gas in EU countries. This process would require the throughput of the pipelines to be expanded within individual countries, which would help to properly distribute natural gas from the input point into the gas system, that is an LNG terminal. The global LNG market is developing dynamically, driven by further investments in liquefaction and regasification facilities. One of them has been built in Poland in recent years. The LNG terminal in 
Świnoujście is of strategic importance in terms of diversification of natural gas supply sources. Apart from LNG terminals, the growing importance of FLNGs and FSRUs can be seen as well. One consequence of this may be the move from long-term contracts towards spot transactions in natural gas trading. Developments taking place in the LNG market increase energy independence and make the market more competitive. The analysis of plans for expansion of energy infrastructure shows that in the coming years new LNG terminals will be built, which may reduce the price of natural gas delivered via pipelines. However, LNG terminals are the facilities that help to switch to a different source of natural gas supply, thus the supplier, in a rapid and flexible manner, which significantly affects both energy security and market competition.

This work has been financed from the funds for statutory research, granted to AGH No. 11.11.190.555, No. 11.11.210.375 and Rzeszów University of Technology.

\section{References}

1. BP Statistical Review of World Energy 2018, https://www.bp.com (2018)

2. A. Wyrwa, Environmental Modelling \& Software, 74, 227-237 (2015)

3. BP Statistical Review of World Energy 2017, https://www.bp.com (2017)

4. J. Stern, The Oxford Institute for Energy Studies, https://www.oxfordenergy.org (2017)

5. P. Mickiewicz, Samorzad, Nauka, Polityka, 77-90 (2014)

6. M. Kaliski, P. Janusz, A. Szurlej, Woda i Technika Sanitarna, 83, 7-8 (2009)

7. M. Ruszel, Przeglad Politologiczny, 2, 49-58 (2015)

8. A. Prontera, M. Ruszel, Middle East Policy, 3,145-162 (2017)

9. D.A. Wood, Journal of Natural Gas Science and Engineering, 36, A1-A4 (2016)

10. M. Bouwmeester, B. Scholtens, Energy Policy, 107, 371-380 (2017)

11. A. Szurlej, M. Ruszel, T. Olkuski, Rynek Energii, 5, 3-10 (2015)

12. P. De Silva, S. Simons, P. Stevens, Energy Policy, 88, 639-651 (2016)

13. PAP/RS 2018, https://gazownictwo.wnp.pl (2018)

14. M. Ruszel, Polityka i Spoleczeństwo, 4(12), 49-59 (2014)

15. The LNG Industry GIIGNL Annual Report 2018, http://www.giignl.org (2018)

16. H. Nikhalat-Jahromi, M. Bell, D. Fontes, R. Cochrane, P. Angeloudis, Energy Policy, 96, 717-725 (2016)

17. A. Sikora, M. Sikora, http://biznesalert.pl (2018)

18. M. Gałczyński, M. Ruszel, M. Turowski, R. Zajdler, A. Zawisza, Ignacy Lukasiewicz Energy Policy Institute (2017)

19. D. Gritsenko, Energy Policy 112, 74-83 (2018)

20. A. Szurlej, P. Janusz, Gospod Surowcami Min, 29, 4, 77-94 (2013)

21. Gas Infrastructure Europe, http://www.gie.eu (2018)

22. R. Biały, P. Janusz, M. Ruszel, A. Szurlej, Zeszyty Naukowe Instytutu Gospodarki Surowcami Mineralnymi i Energia Polskiej Akademii Nauk, 102, 231-244 (2018)

23. P. Janusz, M. Kaliski, M.P. Sikora, A.P. Sikora, A. Szurlej, Polityka Energetyczna, 20(4), 27-38 (2017)

24. A. Sikora, M. Sikora, https://www.cire.pl (2018) 